\title{
MODIFYING AND TESTING THE THRESHING DEVICE FOR GRAIN COMBINE HARVESTER TO SUIT SUNFLOWER THRESHING
}

\author{
EL SAYED, G. H. ${ }^{1}$, M. A. F. ABD EL MAKSOUD ${ }^{2}$ AND S.A.H.M.SHALABY ${ }^{1}$
}

${ }^{1}$ Ag. Eng. Res. Inst., ARC, Dokki, Giza

${ }^{2}$ Ag. Eng. Dep., Fac. Of Ag., Menoufiya Univ.

(Manuscript received 16 June 2009)

\begin{abstract}
Threshing losses (\%), separating losses (\%), shoe losses (\%) and threshing efficiency (\%) were calculated and determined in this investigation as the parameters required for evaluating the performance of the modified threshing device of a cereal crops harvester with the aim to reduce threshing and separating losses and reduce damaged seeds. The main characteristics of the used harvester were CICORIA - T type, longitudinal axial-flow with standard 5 bats reel. The modification was accomplished by replacing the wrapped rasp-bars by shaped prismatic beaters made from steel and fixed (bolted) tightly on the same (6) lines of the original rasp-bars. The factors considered to test and evaluate the performance were combine forward speed of $2.40,2.82,3.30$, and $3.80 \mathrm{~km} / \mathrm{h}$ : seed moisture content of 22.35, 15.15 and 10.75 (\%wet basis): threshing rotor speed of $9.14,10.43,11.73$ and $13.49 \mathrm{~m} / \mathrm{s}$ and concave-rotor clearance ratio of 4.2/2.8and3.25/2.5 . The direction $\mathrm{N} \Leftrightarrow \mathrm{S}$ (North-South) was used in sunflower seed crop harvesting as suggested in a previous study. The results revealed that the least values of threshing, separating and shoe losses were about $(0.18 \%$ or $2.31 \mathrm{~kg} / \mathrm{fed}),(0.14 \%$ or $1.8 \mathrm{~kg} / \mathrm{fed})$ and $(0.11 \%$ or $1.61 \mathrm{~kg} / \mathrm{fed})$ respectively at the forward speed of $3.3 \mathrm{~km} / \mathrm{h}$, clearance ratio of $4.2 / 2.8$ and seed moisture content of the range from 10.75 to $15.15 \%$ wet basis. Rotor speed of $13.49 \mathrm{~m} / \mathrm{s}$ (379.27 rpm) realized the least values of both threshing and separating losses at the previous conditions, while the least values of shoe losses were achieved when the rotor speed decreased from 13.49 to $9.41 \mathrm{~m} / \mathrm{s}$ at the same previous conditions. The lowest value of $0.73 \%$ processing losses (threshing, separating and shoe losses) of the total yield was occurred under 1.5 concave clearance ratio, rotor speed of $11.73 \mathrm{~m} / \mathrm{sec}$ and $15.15 \%$ seed moisture content
\end{abstract}

\section{INTRODUCTION}

Bainer et al. (1982) stated that removal of seeds from the heads or pods is ordinary accomplished with rotating cylinders whose threshing action depends primarily upon impact when the relatively slow-moving material comes in contact with the high-speed cylinder, the impact shatters the heads or pods and frees a 
considerable portion of the seed from the straw. Further threshing is obtained by the rubbing action as the material is accelerated and passes through the restricted clearance space between the cylinder and concave.

Rizvi et al. (1993) conducted a study in order to determine a better threshing unit for a sunflower thresher. The performance of the threshing unit for out put capacity, cleaning efficiency and percentage of brokers were evaluated against different drum types The study showed that the peg type cylinder with a speed range of (400-500 r.p.m) and concave clearance range of $(2.54-4.40 \mathrm{~cm})$ may be used for developing a threshing unit for a sunflower thresher.

Bansal and Dahiya (2001) reported that the threshing efficiency of sunflower seeds mainly depends upon seed moisture content, feeding rate, concave clearance and speed of threshing cylinder. They recommended that sunflower crop can be threshed with axial flow thresher at cylinder speed of $7.14 \mathrm{~m} / \mathrm{s}$, seed moisture content of $30-35 \%(\mathrm{wb})$ at concave clearance of $2.5 \mathrm{~cm}$ to obtained better quality and high seed recovery. Near optimal thresher performance was achieved at $9.13 \%$ moisture content, $180 \mathrm{~kg} / \mathrm{h}$ feed rate, and 500 r.p.m. cylinder speed.

Sharma and Devnani (1980) indicated that threshing efficiency increased with an increase in cylinder speed but decreased by increasing crop moisture content and a direct relation was found between threshing efficiency and feed rate.

Naravani (1987) reported that threshing efficiency increased from 87.50 to $97.43 \%$ as the seed moisture content decreased from 34 to $7.5 \%$ (w.b). The threshing below the value of $7.5 \%$ created problems of cleaning.

EL- Beba, A .M. A. ( 2001 ) : concluded that the optimum condition for sunflower threshing can be achieved at $13.6 \mathrm{~m} / \mathrm{s}$ drum speed, $15 \%$ seed moisture content and 4/2 ( front / rear) drum - concave clearance ratio.

Abdel-Mageed et al. (1994) indicated that increasing the drum and concave clearance decreases the total losses linearly to the clearance value of $4.5 \mathrm{~cm}$ where, a further increase in the clearance resulted in an increase in the total losses.

Abou El-Kheir (1987), found that the amount of grain separation increased when the outlet cylinder concave clearance decreased. At cylinder-concave clearance "Ci/Co" 16/8, 16/10, 16/14 and 16/16 mm the amount of grain separation were 85.2, $78.3,70.0$ and $64.2 \%$ at cylinder speed of $28.4 \mathrm{~m} / \mathrm{s}$ respectively. The above of increase of grain separation was also according to cylinder-concave clearance, where it was greater at higher cylinder speeds.

Flufy and Stone (1983) found that for any particular combine harvester, the level of threshing grain loss depends largely on the forward speed of the harvester. 
Griffin (1976) stated that when either increasing the cylinder speed or decreasing the clearance increased the threshing effect.

Therefore, the objectives of this study were:

1- Modifying the threshing rotor using shaped-prismatic bases made from steel instead of the rasp-bars; to reduce threshing and separating losses and reduce damaged seeds.

2- Estimating the performance of the modified threshing device by using the combine harvester as a sunflower harvester.

\section{MATERIALS AND METHODS}

\section{Modifications carried out on the threshing device:}

The threshing-rotor was modified by replacing the wrapped rasp-bars by a shaped prismatic beaters made from steel and fixed (bolted) tightly on the same (6) lines of the original rasp-bars. The aim of this step was to reduce threshing, separating and cleaning losses and seed damage by adjusting the threshing clearance at inlet and outlet. (the schematic arrangement and dimensions of the threshing, separating and cleaning devices are shown in Figure (1).

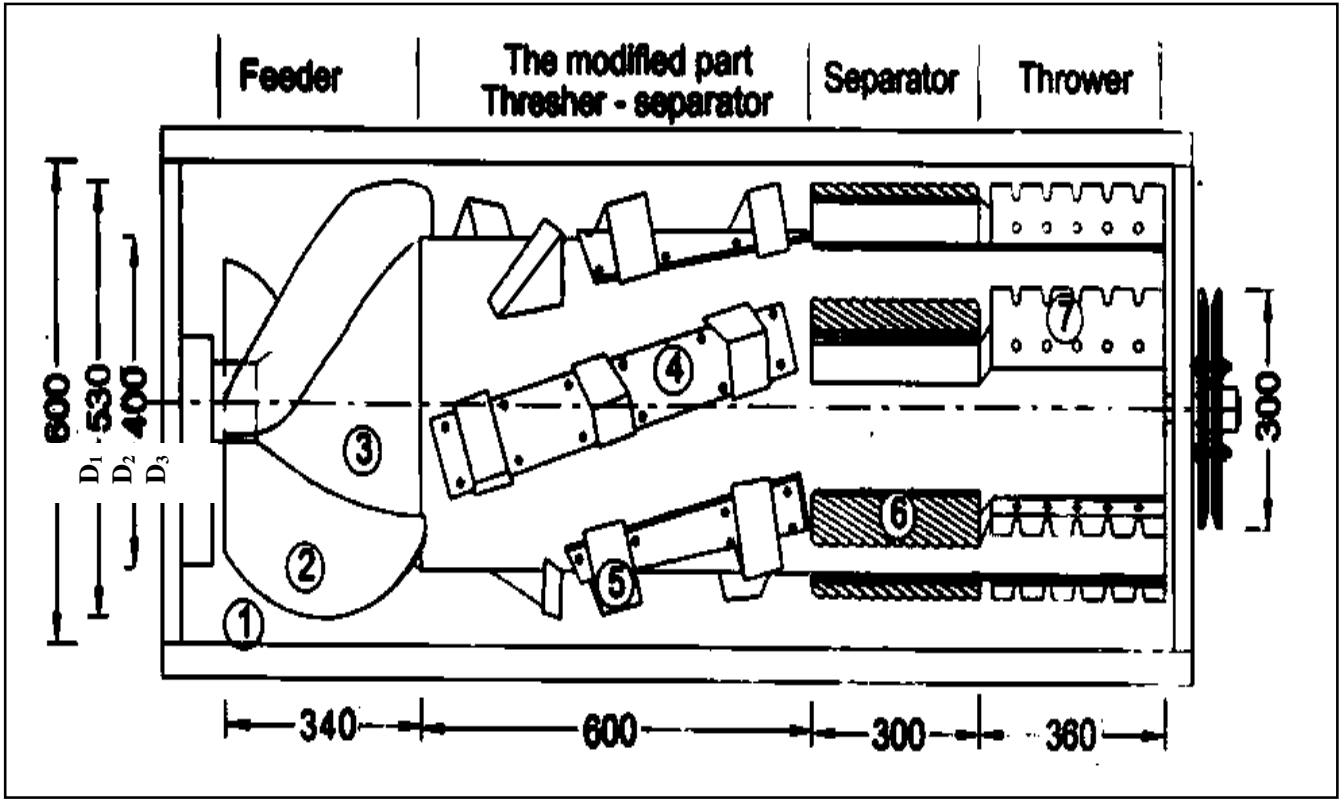

(Dims. in $\mathrm{mm}$ )

$D_{1}=$ diameter of threshing room, $D_{2}=$ outer diameter of threshing rotor $D_{3}=$ inner diameter of threshing rotor

Figure (1): Schematic arrangement and dimensions of the threshing rotor.

1-Treshing room 2-Impeller 3-Conical frontage 4-Original base

5-Prismatic beater 6-Original rasp bar (adj.) 7-Throwing blade (adj.). 


\section{Adjustment of the modified device:}

The following adjustments were carried out at Gemmeiza Research Center workshop and research farms on CICORIA combine harvester for the pre-experimental adjustments:

g. Adjustment and determining the dimensions, position, accounts of the shaped prismatic beaters on the threshing rotor, as shown in Figure (1).

$\mathrm{h}$ Adjustment and determining the accounts of the clearance ratios between the threshing rotor and its concave as shown in Figure (3-a).

Factors affecting the modified threshing device performance in the optimum reaping direction $\left(D_{1}\right)$ :

-Combine forward speed (S): $2.40,2.82,3.30$, and3.80 km/h.

-Seed moisture content (MC): 22.35, 15.15 and 10.75(\%wet basis).

-Threshing rotor speed, with the levels: $9.14,10.43,11.73$ and $13.49 \mathrm{~m} / \mathrm{s}$.

-Concave-rotor clearance ratio, inlet/outlet: 4.2/2.8and3.25/2.5.

As shown in Figure (2). The front and rear clearance in the transverse-cross section of the concave is adjustable clearance ratio which named the lateral clearance ratio and may be described as a ratio of inlet/outlet.

To determine the effects of these factors; the following measurements were taken: threshing losses (\%), separating losses (\%), shoe losses (\%) and threshing efficiency (\%).

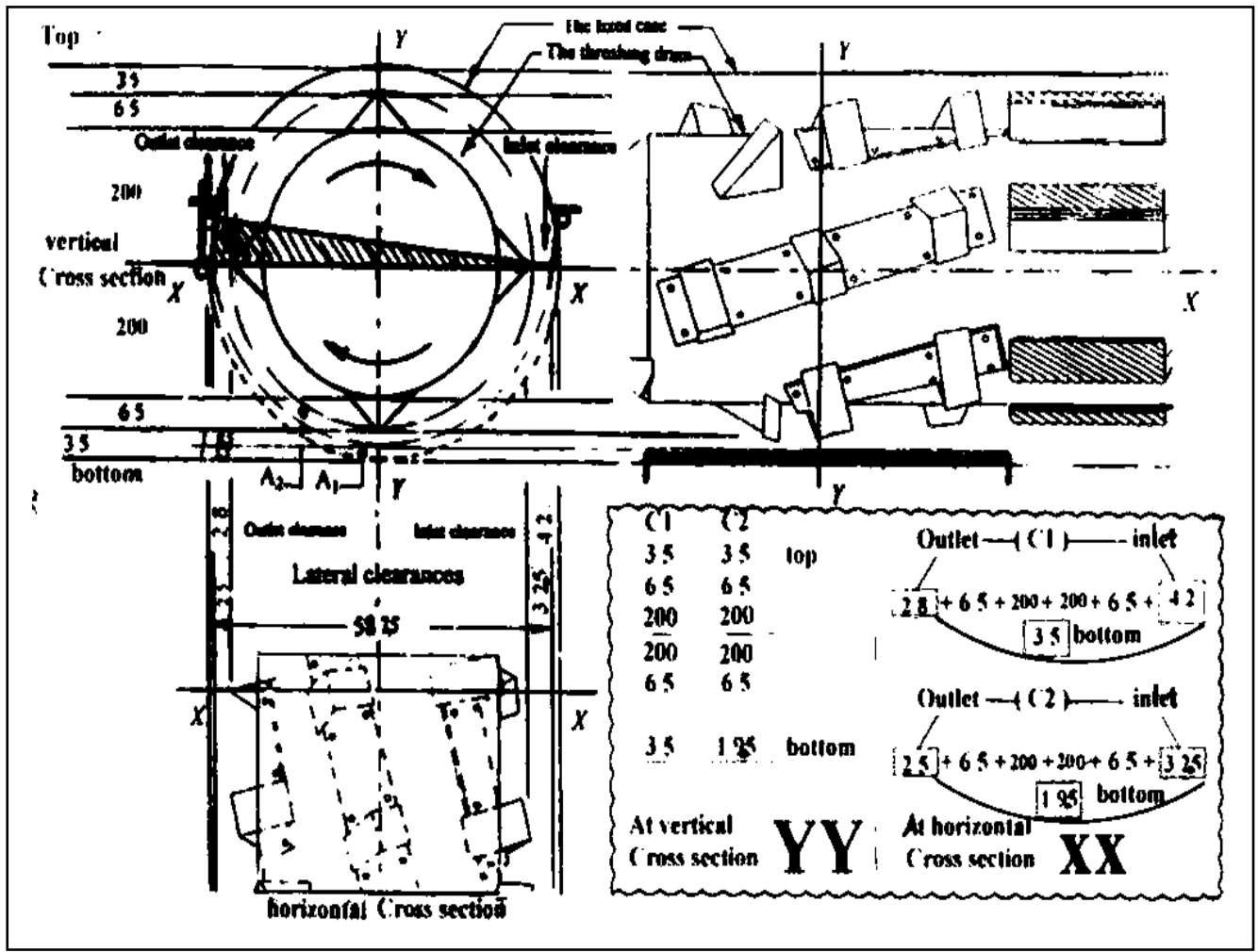

Figure 2. The ranged clearances at the inlet and outlet of the concave

(Dims. in $\mathrm{mm}$ ) 


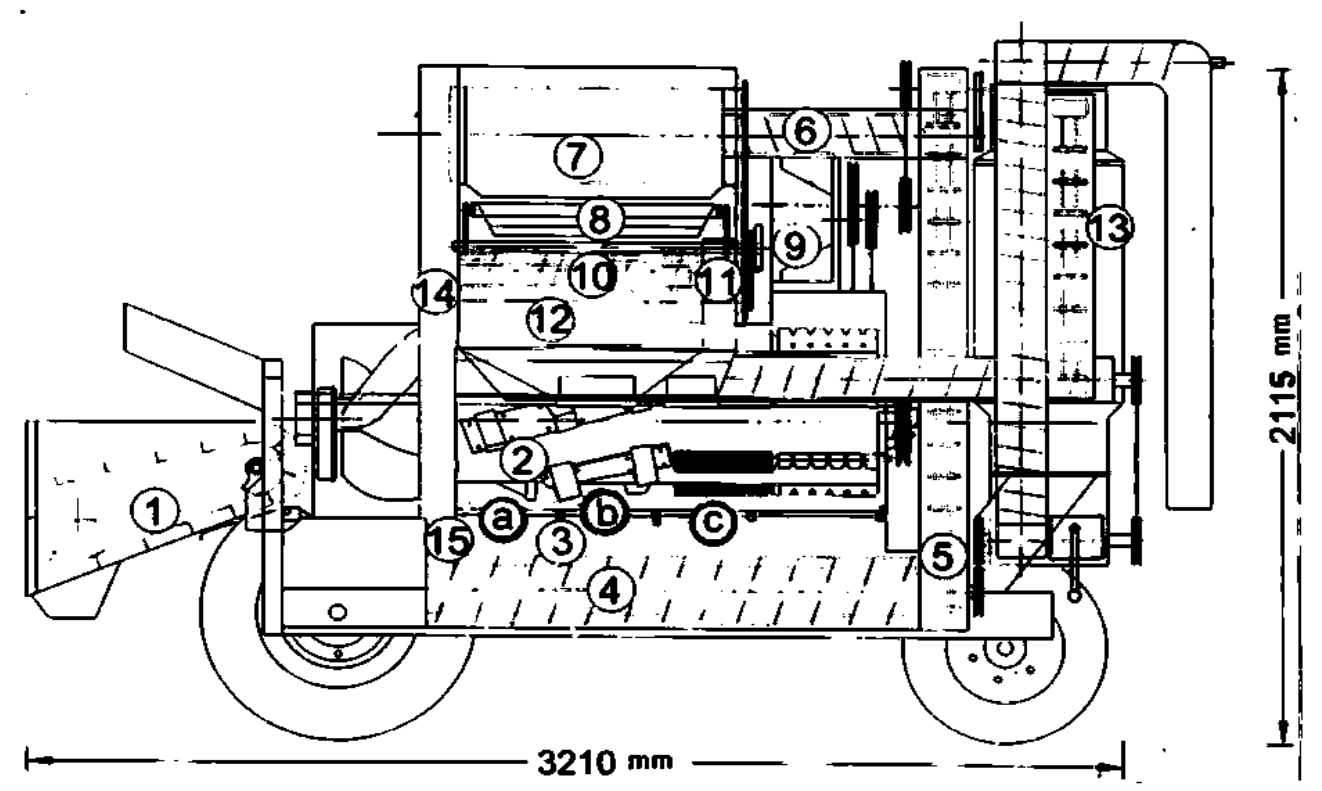

(a)

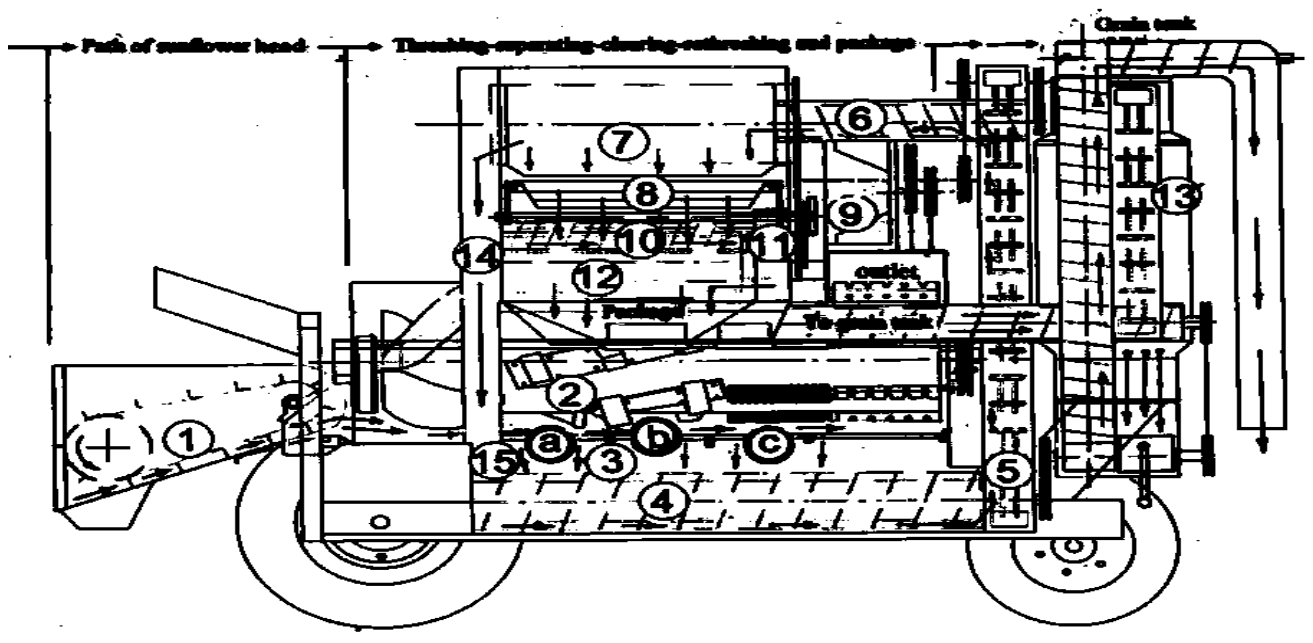

(b)

Figure $(3-a, b)$ : Schematic arrangement of threshing, separating, cleaning devices and crop flow.

1-elevator (heads, necks) 2-threshing rotor3-concave (a,b,c)4-main auger(seed,cours chaff)5-elevator

(seed+cours chaff)6-auger7-firstcylindricsieve8-cleaning shoe ( seed+fine chaff)9cleaning fan10-returning

auger11-rethreshingreel12-secondcylindric sieve13-grain tank14returning collector15returning tube. 


\section{Methods of Measurements}

\section{a. Seed moisture content, (\% wet basis):}

It was measured on harvesting day by two methods.

1. Directly; by using electric moisture tester Model $400 \mathrm{~B}$.

2. The drying method by using an electric oven according to the ASAE standard $\left(130^{\circ} \mathrm{C}\right.$ for 1 hour $)$.

The treatments on moisture samples were determined using the oven method to check the electric tester. The differences between the two methods were about \pm $0.2 \%$.

MC (\% w.b) $=\frac{\text { Sample weight } \text { before drying - sample weight after drying }}{\text { sample weight before drying }}$

\section{b. Combine forward speed, (S), $\mathrm{m} / \mathrm{s}$ :}

The combine forward speeds were measured during harvesting operation using a digital stop watch to record the time needed for travel a distance of thirty five meters long. The lost time as in turning, repairing and cleaning was recorded also $\mathrm{S}=\frac{3.6 \text { distance }(\mathrm{m})}{\text { time consumed }(\mathrm{sec})}=\mathrm{km} / \mathrm{h}$

\section{c. The threshing-rotor speed, $(\mathrm{T}), \mathrm{m} / \mathrm{s}$ :}

The rotor speed was measured directly in R.P.M. using a speedometer (dial tachometer).

Liner speed $=\mathrm{R} \omega$

\section{d. The concave-rotor clearance ratios, (C):}

The concave is divided originally into three equal sections; each of them can be adjusted alone to get the proper clearance loses were collected at the rear of the combine (inlet, $\mathrm{cm} /$ outlet $\mathrm{cm}$ ).

\section{Measurements carried out on the modified threshing and separating unit: Threshing and separating losses:}

Weighed and considered separating losses. Meanwhile, the un threshed seeds were re-threshed manually and then collected, weighed and considered threshing loses. The weight of seeds collected from a specific area was related to the total seed weight from that area (these measurements were done while the machine was traveling at constant speed over a measured and timed distance). To determine the unthreshed and unseparated seeds blown out, a long and wide bag was hanged at the outlet of the threshing section to collect all materials which came out with the straw, then, the separated seeds were,

The percentage of threshing and separating losses were calculated by using the following equations: 
Threshing losses $\%=\frac{\text { Unthreshed seeds }}{\text { Total yield }}$

Separating losses $\%=\frac{\text { Threshed seeds blown out }}{\text { Total yield }}$

\section{Shoe losses \%:}

The mixture of seeds and chaff (straw ashes) received out from the winnowing was collected, then, the seeds were separated manually, weighed to determine the shoe loss:

Shoe losses $\%=\frac{\text { shoe loss }}{\text { total yield }}$

\section{The performance of the modified threshing unit:}

Effect of seed moisture content, forward speed, rotor speed and clearance ratio on threshing losses at the suggested direction $D_{1}$ :

Moisture content:

Figure (4) shows clearly that decreasing moisture content in the levels $22.35,15.15$ and $10.75 \%$ (w.b.) at combine forward speed of $2.4 \mathrm{~km} / \mathrm{h}$, rotor speed of $9.14 \mathrm{~m} / \mathrm{s}$ (332.36 R.P.M) and clearance ratio of $\left(C_{1}\right)$ : decreased threshing losses from 1.36 to 0.80 and $0.52 \%$ respectively. Generally, the percentage of losses was directly proportional to seed moisture content. So, the moisture content of $10.75 \%$ is considered to be recommended for minimum threshing losses $\%$ and maximum threshing efficiency. This is due to the directed effect of the moisture content of the harvested materials including the whole heads with seeds in the threshing room. So, there is a high adherence between this wet materials and both of prismatic bats existing on harvesting rotor and the concave which led to make a layer of materials on the concave grates and consequently increase the friction resistance. In addition, finding damp stalks in the threshed layer makes the seed's separation from head be more difficult than the case of dry stalks or heads.

\section{Forward speed:}

It is noted from Figure (4) that the forward speed has changeable influence on threshing losses. At seed moisture content of $10.75 \%$, it can be noticed that increasing forward speed from 2.82 to $3.3 \mathrm{~km} / \mathrm{h}$ when harvesting by rotor speed of $9.14 \mathrm{~m} / \mathrm{s}$ (332.36 RPM) and rotor-concave clearance ratio of $\left(C_{1}\right)$; the threshing losses decreases from 0.43 to $0.35 \%$ of the total yield, Whereas, more increment in forward speed increases threshing losses. So that, increasing forward speed from 3.3 to 3.8 $\mathrm{km} / \mathrm{h}$ causes increment of threshing losses. This result indicates that the forward speed of $3.30 \mathrm{~km} / \mathrm{h}$ considered the optimum for decreasing of threshing losses under this condition. It can also be noted that the optimum forward speed fore decreasing threshing losses under the other conditions of $\left(M_{2}\right)$ or $\left(M C_{1}\right)$ is the forward speed of 
$3.3 \mathrm{~km} / \mathrm{h}$ and $2.82 \mathrm{~km} / \mathrm{h}$ respectively. This trend of result is due to the differences of feeding rates according to the differences in forward speeds. As forward speed increases the length of cut (neck) decreases, hence, the "gripping capacity" of the drum with sunflower heads increases. In other meaning, for good threshing and screening of seeds through the concave, the drum must size the plant mass uniformly and not allow it to pile up in front of the gap between the drum and the concave.

\section{Rotor speed:}

Figure (4) represents different rotor speeds in respect to threshing losses. It is noted that rotor speed has also changeable influence on threshing losses. It can be noticed that threshing losses decrease from 1.25 to $1.07 \%$ of the total yield as rotor speed increases from 9.14 to $13.49 \mathrm{~m} / \mathrm{s}$ ( 332.36 to 489 RPM)) when harvesting by forward speed of $2.82 \mathrm{~km} / \mathrm{h}$, rotor-concave clearance ratio of $\left(C_{1}\right)$ at seed moisture content of $22.35 \%$ wet basis. Also the rotor speed of $13.49 \mathrm{~m} / \mathrm{sec}$ represents the optimum for decreasing threshing losses under the same conditions at15.15or10.75 (\%w.b.). This result is due to the number of impacts caused by the prismatic beaters on plant mass at entry to the threshing gap. The number of impacts per unit length of the plant and their force (the rotor speed), significantly affect the release of seeds from heads and the deformation of the straw. Then, when the length of stalks is reduced, the grain sieved through the concave decreases since more stalks are trapped between the crossbars of the concave which decreases the cross section of the apertures resulting in poor threshing and separating.

\section{Clearance ratio $(\mathrm{C})$ between rotor and concave:}

Figure (4) shows the effect of two clearance ratios on threshing losses under the other parameters. The data indicates that in case of harvesting by forward speed of $2.4 \mathrm{~km} / \mathrm{h}$, rotor speed of $9.14 \mathrm{~m} / \mathrm{s}$ and clearance ratio of $\left(C_{1}\right)$ at lower seed moisture content of $10.75 \%$; the threshing losses are $0.52 \%$ of the total yield, i.e. (6.69 $\mathrm{kg} / \mathrm{fed}$ ). While the threshing losses of $1.61 \%$, i.e. (20.72 $\mathrm{kg} / \mathrm{fed}$.) is resulted at clearance ratio of $\left(C_{2}\right)$ under the same previous conditions of the other parameters. This trend of result means that increasing the clearance ratio decreases the threshing losses.

This result can be explained by the following: During the threshing operation, the charge is fed to the threshing drum and the beaters, which run at speed greater than that of the plant mass, strike the latter and thresh out part of the seeds. Simultaneously, the drum takes up the mass and draws it through the gap between the beaters and the concave. Seeds are threshed out during this process also. The efficiency of grain threshing increases with increase in the number of impacts and in the threshing gap because of the relative long duration of the plant mass. 
at $22.35 \%$ seed MC at $15.15 \%$ seed $\mathrm{MC} \quad$ at $10.75 \%$ seed MC
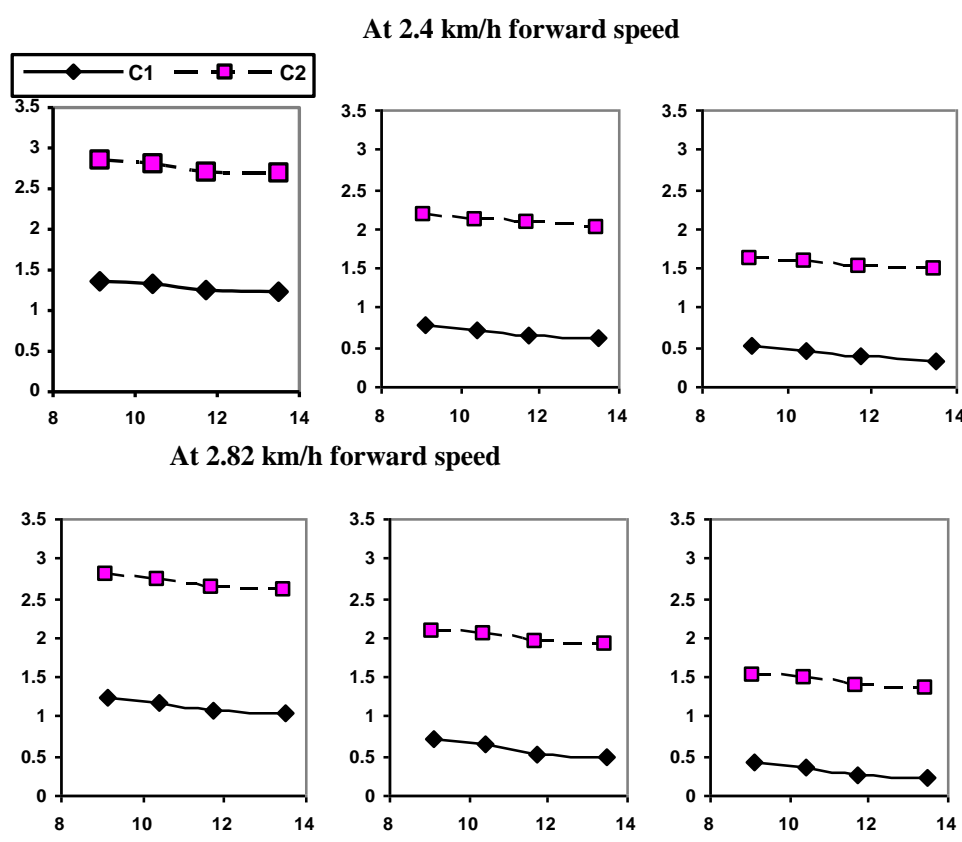

है

At $3.30 \mathrm{~km} / \mathrm{h}$ forward speed
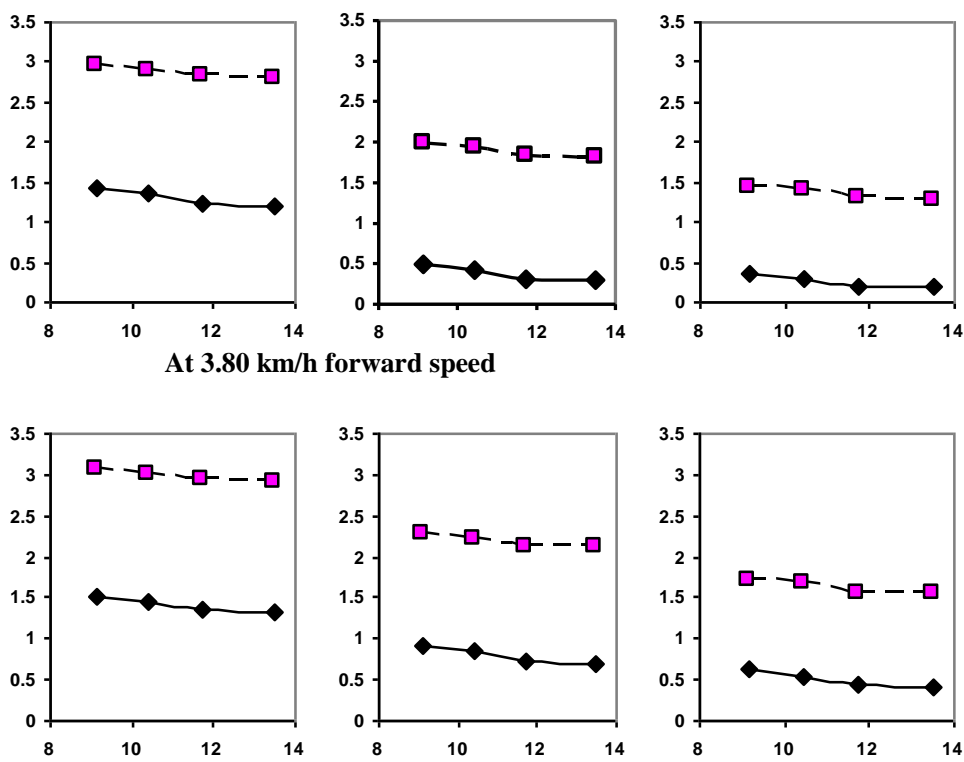

Rotor speed $(\mathrm{T}) \mathrm{m} / \mathrm{s}$

Figure 4. Effect of rotor speed and rotor-concave clearance ratio on threshing losses, at different forward speeds and seed moisture contents

$$
\left(c_{1}=1.5: 1, c_{2}=1.3: 1\right) \text {. }
$$

The regression analysis of data clarified the same trend of results. The following mutable linear equations revealed that there are differences between the means of the threshing losses \% as affected by the different levels of both machine forward 
speed $(\mathrm{km} / \mathrm{h})$, rotor speed $(\mathrm{m} / \mathrm{sec})$, seed moisture content $\%(\mathrm{w} . \mathrm{b})$ and the clearance ratio $(\mathrm{C})$ :

$T_{h r} . L, \%=9.7+0.23 S-0.044 T+0.097 M c-6.810 C \quad\left(R^{2}=0.97\right)$

Where: $\mathrm{S}=$ forward speed $(\mathrm{km} / \mathrm{h}) \quad, \mathrm{T}=\operatorname{rotor}$ speed $(\mathrm{m} / \mathrm{s})$

$\mathrm{M}_{\mathrm{C}}=$ seed moisture content (w.b) , $\mathrm{C}=$ rotor - concave clearance:

$\mathrm{C}_{1}=\frac{4.2}{2.8}=1.5 \quad, \mathrm{C}_{2}=\frac{3.25}{2.5}=1.3$

Effect of seed moisture content, forward speed, rotor speed and clearance ratio on separating losses:

\section{Moisture content:}

The effects of seed moisture contents on separating losses \% are shown in Figure (5). It is noted that decreasing seed moisture content from 22.35 to 15.15 (\%w.b.) at forward speed of $3.3 \mathrm{~km} / \mathrm{h}$, rotor speed of $13.49 \mathrm{~m} / \mathrm{s}$ (489 RPM), and clearance ratio of $\left(C_{1}\right)$ : the separating losses decreased from $0.84 \%$ to $0.20 \%$ respectively. Furthermore, decrement of moisture content from 15.15 to $10.75 \%$ under the same conditions; the separating losses slightly decreased from 0.20 to $0.14 \%$. So that, the moisture content of $10.75 \%$ is recommended for decreasing the separating losses and increasing the separating efficiency. This result is due to the higher values of adherence between both of the concave grates and the individual components of the plant mass; penetration of grains through the shifter layer is more difficult (slower). This is the same cause in threshing damp material, the amount of released grain (in percent) at the same slit width is distingly smaller than the case of drier material.

\section{Forward speed:}

It is clear from Figure (5) that combine forward speed has a changeable effect on separating losses. At seed moisture content of $10.75 \%$ (w.b) ,the increasing of forward speed from 2.82 to $3.30 \mathrm{~km} / \mathrm{h}$ at rotor speed of $13.49 \mathrm{~m} / \mathrm{s}$ (489 RPM), and rotor-concave clearance ratio of $\left(C_{1}\right)$; the separating losses decreased from 0.21 to $0.14 \%(1.80 \mathrm{~kg} / \mathrm{fed}$.). Whereas more increment in forward speed increases separating losses. For example increasing forward speed from of $3.3 \mathrm{~km} / \mathrm{h}$ to $3.80 \mathrm{~km} / \mathrm{h}$ resulted in increasing of the separating losses by $0.43 \%$. This trend indicates that the forward speed of $3.3 \mathrm{~km} / \mathrm{h}$ is considered to be the optimum for decreasing the separating losses under the previous conditions. This result is due to the excessive feeding rate caused by increasing the forward speed. Then, the threshing of crop, seed spillage and the break up of the straw are significantly affected, specially when the length of the stalks is increased, the grain sieved through the concave decreases since more stalks are trapped between the cross bars and consequently reduce cross section of the apertures. 


\section{Rotor speed:}

Figure (5) shows the effect of different rotor speeds on separating losses. It is obvious that rotor speed has changeable influence on separating losses. When harvesting at forward speed of $3.30 \mathrm{~km} / \mathrm{h}$, and seed moisture content of $15.15 \%$ (w.b) it was noticed that separating losses

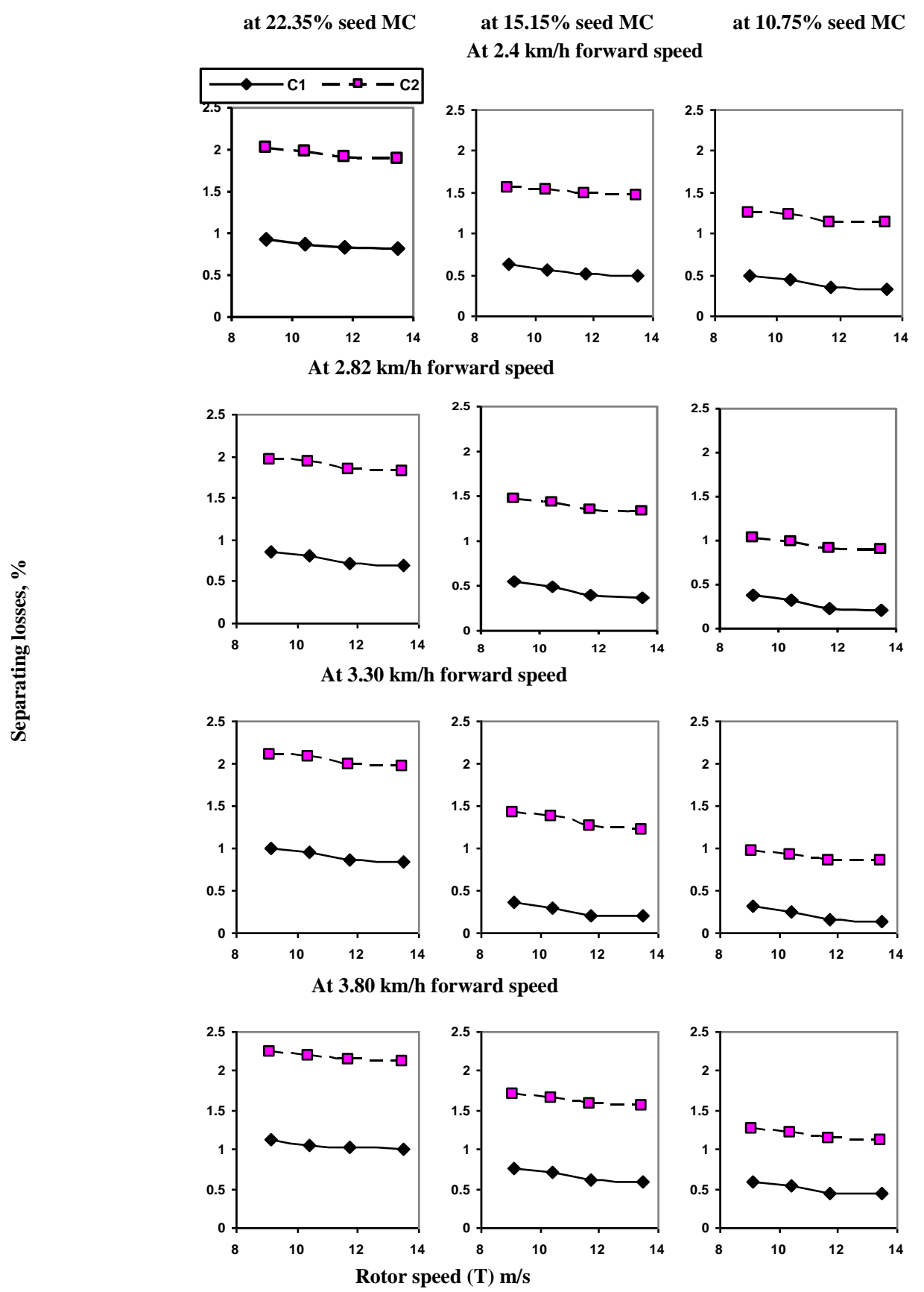

Figure 5. Effect of rotor speed and rotor-concave clearance on separating losses, at different forward speeds and seed moisture contents $\left(c_{1}=1.5: 1, c_{2}=1.3: 1\right)$. 
decreased from 0.35 to $0.18 \%$ as rotor speed increased from 9.14 to 13.49 $\mathrm{m} / \mathrm{s}(332.36$ to $489 \mathrm{RPM})$, and at rotor-concave clearance ratio of $\left(\mathrm{C}_{1}\right)$

This result means that the rotor speed of $13.49 \mathrm{~m} / \mathrm{s}$ is the optimum for reducing separating losses. This behavior is owing to the action of high rotor speed which causes breakage of the straw as it increases. When rotor speed is lower the length of the breakage stalks is increased and, the grain sieved through the concave decreases since more stalks are trapped between the cross bars which decreases the cross section of the apertures causing more separating losses.

\section{Clearance ratio $(\mathrm{C})$ between rotor and concave:}

Data obtained and represented in Figure (5) show the effects of two clearances on separating losses. The data indicate that, in case of harvesting at forward speed of $2.82 \mathrm{~km} / \mathrm{h}$, rotor speed of $11.73 \mathrm{~m} / \mathrm{s}$ and clearance ratio of $\left(C_{1}\right)$, and seed moisture content of $10.75 \%$ (w.b); the separating losses was $0.23 \%$ decreasing clearance ratio to C2 resulted in higher separated losses of $0.91 \%(11.71 \mathrm{~kg} / \mathrm{fed})$ This result means that decreasing the clearance ratios increase the separating losses.

This result can be explained as following: During the threshing operation, the plant mass moves through the space between the rotor and the concave at speed lower than the speed of the prismatic beaters. Hence, the plant mass subjected to continuous impacts along the concave, then, efficiency of seed separating increases with increment in the number of impacts and in the threshing gap between the rotor and the concave because of the relative long duration of the plant mass.

The regression analysis of data indicated the same trend of previous results. The obtained regression equation revealed that there are effective differences between the means of separating losses $\%$ as affected by the different levels of machine forward speed $\mathrm{km} / \mathrm{h}$, rotor speed $\mathrm{m} / \mathrm{sec}$, seed moisture content ( $\% \mathrm{w} . \mathrm{b}$ ) and the clearance ratio (C): as follows:

$L, \%=6.56+0.24 \mathrm{~S}-0.038 \mathrm{~T} .+0.062 \mathrm{Mc}-4.501 \mathrm{C} \quad\left(\mathrm{R}^{2}=0.90\right)$, Where:

$$
\begin{aligned}
& \mathrm{L}, \%=\text { percent of separating losses } \%, \mathrm{~S}=\text { forward speed }(\mathrm{km} / \mathrm{h}) \\
& \mathrm{T}=\text { rotor speed }(\mathrm{m} / \mathrm{s}), \quad \mathrm{MC}=\text { seed moisture content }(\% \mathrm{w} . \mathrm{b}) \\
& \mathrm{C}=\text { rotor }- \text { concave clearance ratio: } \mathrm{C}_{1}=\frac{4.2}{2.8}=1.5, \mathrm{C}_{2}=\frac{3.25}{2.5}=1.3 .
\end{aligned}
$$

\section{Effect of seed moisture content (MC), forward speed (S), rotor speed (T) and clearance ratio $(\mathrm{C})$ on shoe losses \%: Moisture content:}

Figure (6) shows clearly the effect of seed moisture content on shoe losses \% under different other parameters. It was noticed that decreasing moisture content from $22.35 \%$ to $15.15 \%$ (w.b) at forward speed of $(3.30 \mathrm{~km} / \mathrm{h})$, rotor speed of 13.49 $\mathrm{m} / \mathrm{s}(4.89 \mathrm{RPM})$ and clearance ratio $\left(\mathrm{C}_{1}\right)$, tended to decrease shoe losses from $0.92 \%$ to $0.27 \%$. Further more decrement of moisture content from $15.15 \%$ to $10.75 \%$ under the same previous conditions; the shoe losses increased from $0.27 \%$ to $0.47 \%$. So that, the moisture content of $15.15 \%$ is considered to be recommended for minimum shoe losses, and maximum shoe efficiency. This result can be explained as following: when harvesting at high moisture content, the threshed grain may contain pieces of herbage and damp straw that cannot be effectively removed while wet, 
clogs the screens causing more cleaning losses. On the other side: when harvesting at lower moisture content, the excessive breaking of dry straw makes straw baling more difficult to move making overload the separating and cleaning mechanisms by creating more broken pieces of dry straw causing more shoe losses and absorbs more power.

\section{Forward speed:}

Figure (6) represents different machine forward speeds with respect to the shoe losses, \% that affected by moisture content and the other parameters. It is noted that at seed moisture content of $10.75 \%$ (w.b) the increasing of forward speed from 2.82 to $3.3 \mathrm{~km} / \mathrm{h}$ as harvesting by rotor speed of $10.43 \mathrm{~m} / \mathrm{s}$ (379.27 RPM) through rotorconcave clearance ratio of $\left(C_{1}\right)$ causes decrement in shoe losses from $0.44 \%$ to $0.32 \%$ of the total yield,. Whereas, more increment in forward speed increases shoe losses. Consequently increasing the forward speed from 3.3 to $3.80 \mathrm{~km} / \mathrm{h}$ caused an increment in shoe losses. This result indicates that the forward speed of $3.3 \mathrm{~km} / \mathrm{h}$ considered the optimum for decreasing of shoe losses under the previous conditions. This trend of result is due to the differences of feeding rates owing to the differences in forward speed levels. The excessive feed rate will tend to overload the separating and shoe mechanisms by creating more broken pieces of straw, and any adjustment of the chaffer-sieve will influence the tailings return, as will as the cleaning on the shoe sieves causing more cleaning losses. Meanwhile, in case of lower forward speed, the feeding rate is not enough to full the threshing capacity (the cylinder needs to be kept fairly fall). So that, the effectiveness of threshing or separating will be lower and so the shoe losses would be high.

\section{Rotor speed:}

Figure (6) represents different rotor speeds in respect to shoe losses \%. It is noted that rotor speed has changeable influence on shoe losses. At seed moisture content of $15.15 \%$ (w.b) it can be noticed that shoe losses increase from $0.23 \%$ to $0.39 \%$ of the total yield, as rotor speed increases from $9.14 \mathrm{~m} / \mathrm{s}$ (33236 RPM) to $13.49 \mathrm{~m} / \mathrm{s}$ (379.27 RPM) when harvesting by forward speed of $2.82 \mathrm{~km} / \mathrm{h}$, through rotor-concave clearance ratio of $\left(C_{1}\right)$. This result indicates that the rotor speed of 9.14 $\mathrm{m} / \mathrm{s}$ (332 RPM) is optimum for decreasing the shoe losses under the previous conditions. This trend of result is due to the severity in the action of increasing rotor speed. This tend to overload the separating and cleaning mechanisms by creating more broken pieces of straw causing more shoe losses.

\section{Clearance ratio $(\mathrm{C})$ between rotor and concave}

Figure (6) shows the effect of two clearance ratios on shoe losses $\%$ under the other parameters. The obtained data indicates that in case of harvesting by forward speed of $3.30 \mathrm{~km} / \mathrm{h}$, rotor speed of $13.49 \mathrm{~m} / \mathrm{s}$ and rotor-concave clearance ratio of $\left(C_{1}\right)$ at seed moisture content of 15.15 (w.b) resulted in shoe losses of $0.27 \%$ (3.95 $\mathrm{kg} / \mathrm{fed}$.). Meanwhile, the shoe loses of $1.03 \%$ (19.49 $\mathrm{kg} / \mathrm{fed}$.) were resulted at clearance ratio of $\left(\mathrm{C}_{2}\right)$ under the same previous conditions of the other parameters. This trend means that decreasing the clearance ratio increases the cleaning losses. This result often due to the big pieces of wet or dry straw, which adds to grain separation through shoe sieves problems, makes straw baling more difficult and then increase the shoe losses \%. The regression analysis of data clarified the same trend of results. The following regression equation revealed that there are differences between 
means of shoe losses \% as affected by the different levels of both machine forward speed $(\mathrm{km} / \mathrm{h})$, rotor speed $(\mathrm{m} / \mathrm{sec})$, seed moisture content (\%w.b) and the clearance ratio $(\mathrm{C})$ :

at $22.35 \%$ seed $M C$

at $15.15 \%$ seed MC

at

\section{$10.75 \%$ seed MC}

At $2.4 \mathrm{~km} / \mathrm{h}$ forward speed
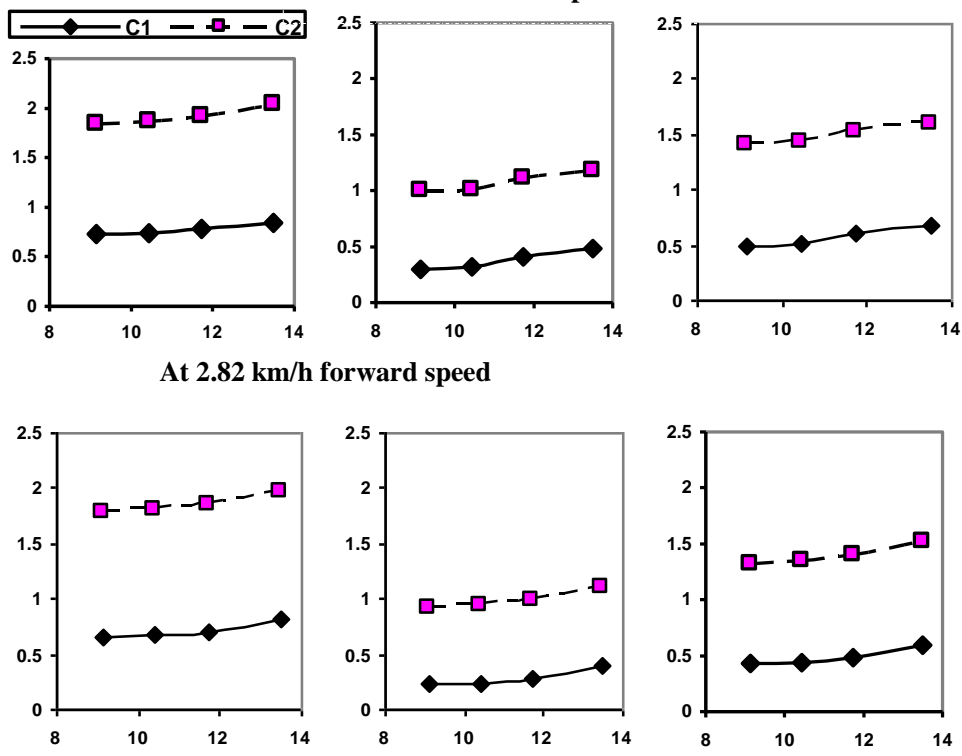

At $3.30 \mathrm{~km} / \mathrm{h}$ forward speed
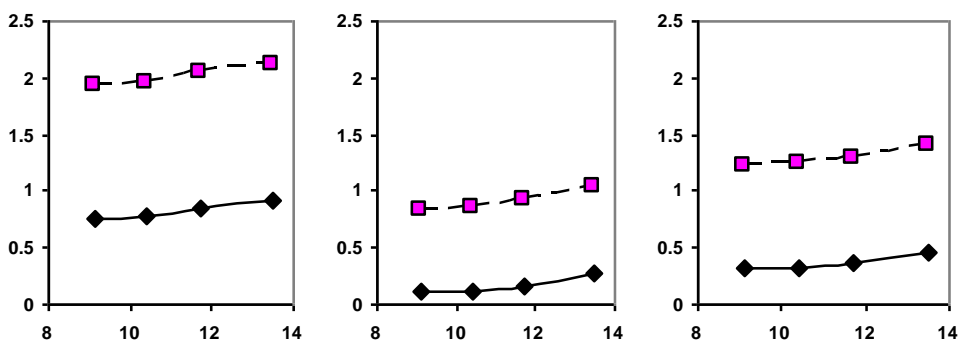

At $3.80 \mathrm{~km} / \mathrm{h}$ forward speed
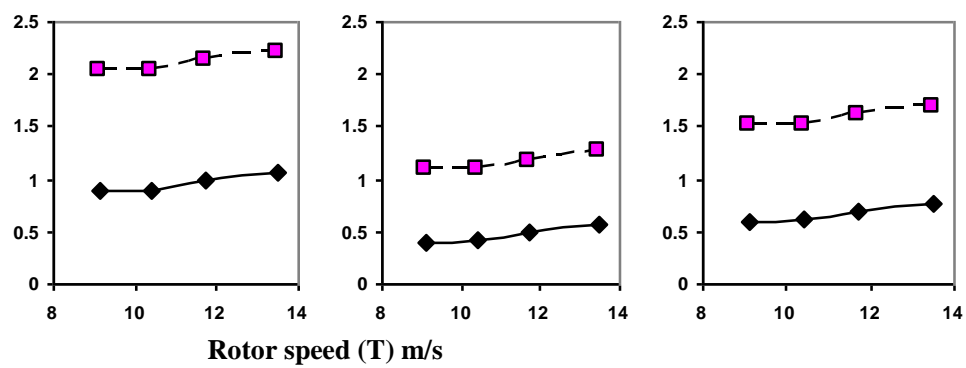

Figure 6. Effect of rotor speed and rotor-concave clearance ratio on shoe losses, at forward speed levels and seed moisture contents $\left(c_{1}=1.5: 1, c_{2}=1.3: 1\right)$.

$L_{S h} \%=6.1+0.28 S+0.0421 T+0.0420 M C \%-4.62 C \quad\left(R^{2}=0.80\right)$

Where:

$\mathrm{L}_{\text {Sh, }} \%=$ percent of shoe losses

, $\mathrm{S}=$ forward speed $\mathrm{Km} / \mathrm{h}$

$\mathrm{T}=$ rotor speed $\mathrm{m} / \mathrm{s}$

, $\mathrm{C}=$ rotor - concave clearance ratio 
$\mathrm{MC} \%$ = percent of seed moisture content, $\mathrm{C}_{1}=\frac{4.2}{2.8}=1.5, \mathrm{C}_{2}=\frac{3.25}{2.5}=1.3$

Effect of rotor peripheral speed ( $T$ ) and rotor concave clearance ratio (C) on processing losses (\%) under different levels of seed moisture content (Mc)

Figure (7) and Table (1) show the data of threshing losses \%, separating losses $\%$ and shoe losses $\%$ as affected by rotor peripheral speed $(\mathrm{T})$ and rotor-concave clearance ratio (c).

Data appear that the highest value of threshing loss \% of total yield was $(2.95 \%)$ and occurred at rotor speed of $9.14 \mathrm{~m} / \mathrm{sec}$ under the rotor-concave clearance ratio of 1.3 and seed moisture content of $22.35 \%$ wet basis. While the lowest value was 0.18 $\%$ and recorded at rotor speed of $13.49 \mathrm{~m} / \mathrm{sec}$ under the concave clearance ratio of 1.5 at seed moisture content of $10.75 \%$, (w.b.). The same trend of result could be seen for the separating loss\%. Meanwhile, the highest value of shoe losses was $2.12 \%$ of the total yield and recorded under rotor-concave clearance ratio of 1.3 at rotor speed of $13.49 \mathrm{~m} / \mathrm{sec}$ at seed moisture content of $22.35 \%$.In this concern the lowest value was $0.11 \%$ of the total yield and occurred at rotor speed of $9.14 \mathrm{~m} / \mathrm{sec}$ under seed moisture content of $15.15 \%$ (w.b) at concave clearance ratio of 1.5 . These results indicate that rotor speed of (13.49) $\mathrm{m} / \mathrm{sec}$, concave clearance ratio of (1.5) and seed moisture content of $10.75 \%$ (w.b) are recommended for recording the lowest values of both threshing and separating losses\%. While the rotor speed of (9.14) $\mathrm{m} / \mathrm{sec}$ under concave clearance ratio of (1.5) at seed moisture content of $15.15 \%$ are recommended for the minimum clearing losses\%. It could be seen that the highest total processing losses of $6.98 \%$ of the total yield was recorded under the conditions: concave clearance ratio of 1.3 , rotor speed of $9.14 \mathrm{~m} / \mathrm{sec}$ and $22.35 \%$ seed moisture content. While the lowest value of $0.73 \%$ processing losses of the total yield was occurred under 1.5 concave clearance ratio, rotor speed of $11.73 \mathrm{~m} / \mathrm{sec}$ and $15.15 \%$ seed moisture content. Hence, the later conditions are recommended for the lowest total processing losses.

The regression analysis of the data indicated the same trends within the following equations:

$$
\begin{aligned}
& \mathrm{L}_{\mathrm{Th},} \%=10-0.0373(\mathrm{~T})+0.112(\mathrm{MC}) \%-7.3 \quad \text { (C) } \quad R^{2}=0.962
\end{aligned}
$$

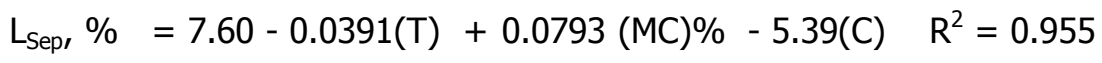

$$
\begin{aligned}
& L_{S h} \%=7.0+0.0397(T)+0.0572(M C) \%-5.39(C) \quad R^{2}=0.906 \\
& \mathrm{~L}_{\mathrm{T}}, \% \%=28-0.0558(\mathrm{~T})+0.104(\mathrm{MC}) \% \quad-18.2(\mathrm{C}) \quad \mathrm{R}^{2}=0.934 \\
& \text { Where: } \mathrm{L}_{\mathrm{Th}} \%=\text { Percent age of Threshing losses } \\
& \mathrm{L}_{\mathrm{Th}}, \%=\text { percent age of Separating losses } \\
& \mathrm{L}_{\text {Sh, }} \%=\text { percent age of Shoe losses }
\end{aligned}
$$




\section{$\mathrm{L}_{\mathrm{T}}, \%=$ percent age of Total Processing Losses}

$\mathrm{T}=$ rotor speed $(\mathrm{m} / \mathrm{s}) \quad, \mathrm{MC}, \%=$ percent of seed moisture content

$C=$ rotor - concave clearance: $C_{1}=4.2 / 2.8=1.5, C_{2}=3.25 / 2.5=1.3$

Table 1. Effect of rotor peripheral speed $(T)$ and rotor-concave clearance $(C)$ on processing losses under different levels of seed moisture contents (MC) \%.

(A)

(B)

(C)

\begin{tabular}{|c|c|c|c|c|c|c|c|}
\hline \multirow{2}{*}{$\begin{array}{c}\text { Rotor } \\
\text { speed } \\
(\mathrm{T}), \mathrm{m} / \mathrm{s}\end{array}$} & \multirow{2}{*}{$\begin{array}{l}\text { combine } \\
\text { losses, \% }\end{array}$} & \multicolumn{2}{|c|}{$\begin{array}{c}M C_{1}=22.35 \% \\
\text { Yield: } 1731.17 \mathrm{~kg} / \mathrm{fed}\end{array}$} & \multicolumn{2}{|c|}{$\begin{array}{c}M C_{2}=15.15 \% \\
1466.36\end{array}$} & \multicolumn{2}{|c|}{$\begin{array}{c}M_{3}=10.75 \% \\
1287.59 \\
\end{array}$} \\
\hline & & $\mathrm{C}_{1}$ & $\mathrm{C}_{2}$ & $\mathrm{C}_{1}$ & $\mathrm{C}_{2}$ & $\mathrm{C}_{1}$ & $\mathrm{C}_{2}$ \\
\hline \multirow{4}{*}{9.14} & Threshing & 1.42 & 2.95 & 0.49 & 1.99 & 0.35 & 1.44 \\
\hline & Separating & 1.01 & 2.10 & 0.36 & 1.40 & 0.32 & 0.95 \\
\hline & shoe & 0.76 & 1.93 & 0.11 & 0.83 & 0.31 & 1.21 \\
\hline & Total & 3.19 & 8.98 & 0.96 & 4.27 & 0.98 & 3.60 \\
\hline \multirow{4}{*}{10.43} & Threshing & 1.35 & 2.90 & 0.42 & 1.94 & 0.28 & 1.39 \\
\hline & Separating & 0.95 & 2.06 & 0.30 & 1.36 & 0.25 & 0.92 \\
\hline & mive & 0.77 & 1.95 & 0.12 & 0.86 & 0.32 & 1.23 \\
\hline & Total & 3.07 & 6.91 & 0.84 & 4.16 & 0.85 & 7.54 \\
\hline \multirow{4}{*}{11.73} & Threshing & 1.24 & 2.83 & 0.31 & 1.84 & 0.20 & 1.29 \\
\hline & Separating & 0.88 & 1.98 & 0.21 & 1.25 & 0.16 & 0.84 \\
\hline & shoe & 0.86 & 2.05 & 0.16 & 0.91 & 0.36 & 1.28 \\
\hline & Total & 2.98 & 6.86 & 0.73 & 4.00 & 0.73 & 3.41 \\
\hline \multirow{4}{*}{13.49} & Threshing & 1.21 & 2.80 & 0.30 & 1.82 & 0.18 & 1.27 \\
\hline & Separating & 0.84 & 1.96 & 0.20 & 1.20 & 0.14 & 0.83 \\
\hline & shoe & 0.92 & 2.12 & 0.27 & 1.03 & 0.17 & 1.34 \\
\hline & Total & 2.96 & 6.88 & 0.77 & 4.05 & 0.79 & 3.49 \\
\hline
\end{tabular}




\begin{tabular}{|llll|}
\hline$\square-T h r . L$ & $-\Delta-$ Sep.L & $--\infty--$ Sh.L & $-*-$ Tot.L \\
\hline
\end{tabular}

Clearance $\left(\mathrm{C}_{1}\right)=$

$4.2 / 2.8$
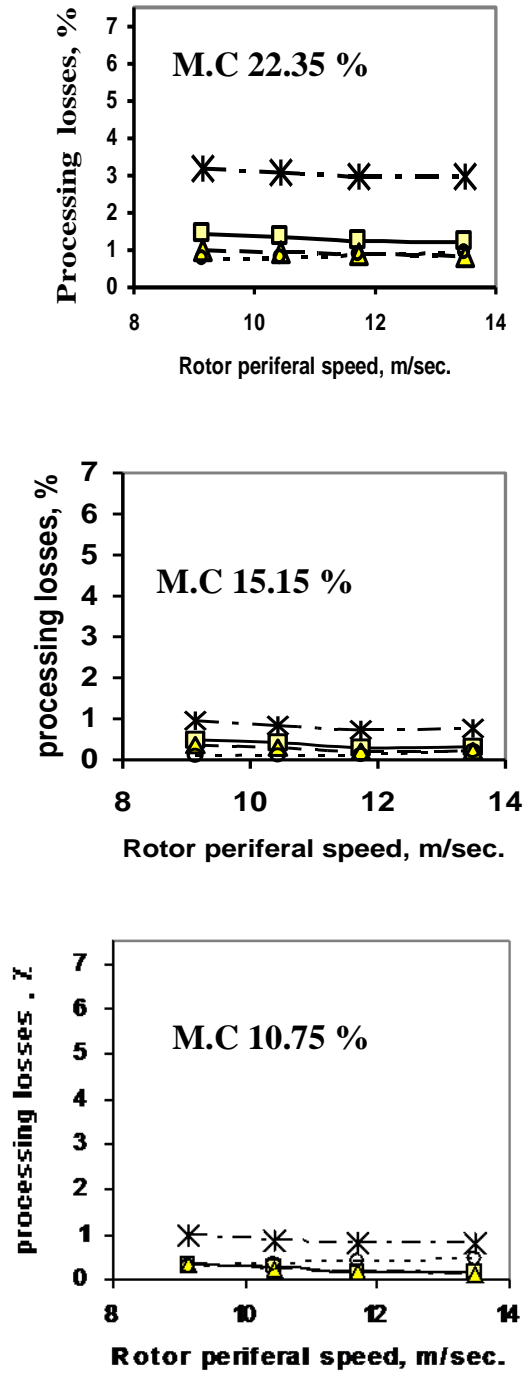

Clearance $\left(\mathrm{C}_{2}\right)=$

$3.25 / 2.5$
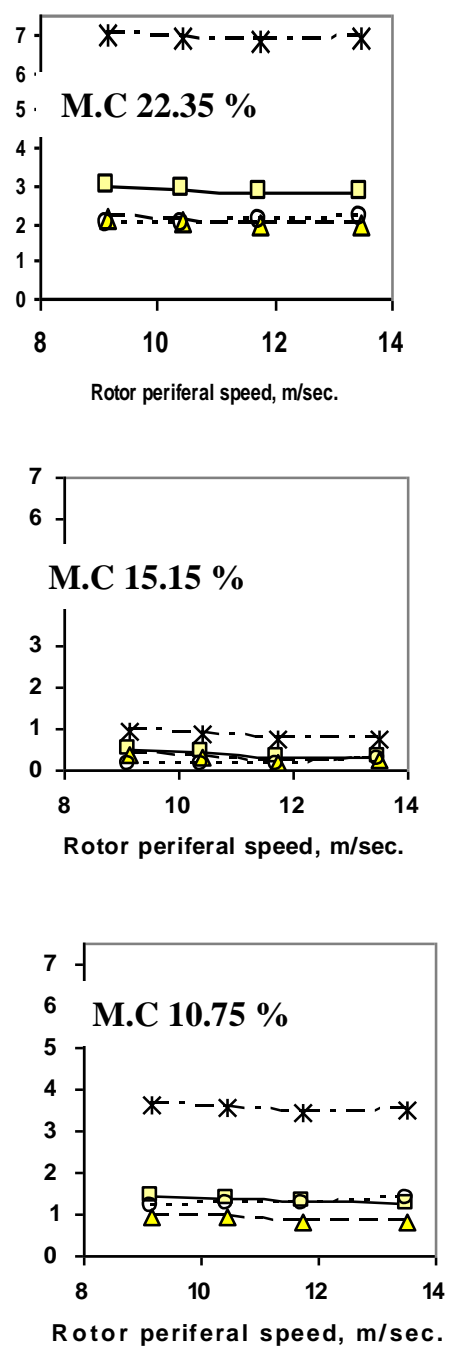

Figure 7. Effect of threshing rotor peripheral speed and rotor-concave clearance ratio on processing losses at different of seed moisture content. 


\section{REFERENCES}

1. Rizvi, S.H.A., Nadeem-Amjad and M.A. Shaheen. 1993. Comparative performance of different threshing drums for sunflower. Farm machinery Institute. Pakistan Agric. Res. Council. Park Road. Agric. Mech. in Asia-Africa and Latin America. 1993, 24: 1, 23-27; 9 ref.

2. Bansal, N.K. and B.S. Dahiya. 2001. Effect of threshing techniques on quality of sunflower seed? seed technology Center, CCS Haryana Agricultural Univ. Hisar125004, India. Seed-Research. 2001, 29; 1, 52-57; 7 ref.

3. Sharma, K.D. and R.S. Devnani. 1980. Threshing studies on soybean and cowpea . AMA. 35(3): 65-68.

4. Naravani, N.B. 1987. Investigations on the performance of Mysore Mini Thresher for efficient threshing of sunflower corp. Agric. Eng. Inst. Raichur-584101 (Karnatoka). India, The role of Agricultural Engineering in dry land Agriculture. Proceedings of the $23^{\text {rd }}$ Annual Convention of the Indian Society of Agricultural Engineers. Jaba (Pur. India. 9-11 Mach 1987, 62-66' 3 ref.

5. El-Peba, A.M.A. 2001. " A study on a modified local machine for threshing sunflower " M.Sc. thesis Agric . Mech .Dept . Faculty of Agric. Mansoura Univ. pp. 91

6. Abou El-Khair, M.M. 1987. Distribution of grain separation and broken straw under concave grate of wheat thresher . Misr. J. Agric. Eng. 4(1).

7. Flufy, M.T. and G.T. Stone. 1983. Speed control of a combine harvester to maintain level of measured threshing grain loss. J. Agric. Eng. Res., 28: 537-543.

8. Griffin, G.A. 1976. Fundamentals of machine operations combine harvesting, John Deer Service Publication, p. 134-156. 


\section{تعديل و اختبار جزء الاراس في آلة حصاد الحبوب الجامعة \\ لتناسب دراس محصول عباد الثمس جرس}

جمال حسن السيد' ، محمد عبد الفتاح عبد المقصود` ، سمير عبد الحميد مصطفى شلبى'

$$
\begin{aligned}
& \text { ا معهد بحوث الهندسة الزراعية - مركز البحوث الزراعية - الدقى - جيزة. } \\
& \text { r قسم الهندسة الزراعية - كلبة الزراعة - جامعة المنوفية. }
\end{aligned}
$$

أجرى هذا البحث بغرض عمل تعديل مناسب لجهاز الدراس فى كومباين أوربي صمم خصيصا

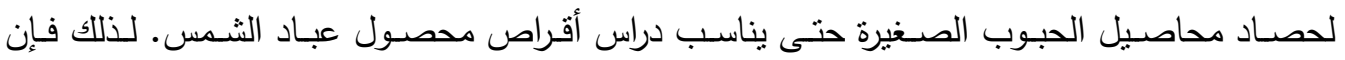
الكومباين ماركة شيكوريا من النوع على شكل حرف (T) ، موديل سريان محوري طولي ذو مضرب ضم يحتوى على خمسة مضارب قد استخدم فى إتمام هذه الدراسة بعد تعديله. وقد اشتملت عملية التعديل على الآتي: 1- عملية تعديل أسطوانة الدراس بغرض تقليل فواقد كل من الدراس والفصل والتتظيف والطاقة المطلوبـة للحصـاد عند سـرعة تقدم عاليـة نسبيا وبغرض زيـادة كفاءة الحصـاد والسعة الحقليـة للآلـة وإنتاجية الحبوب. تم زراعة مساحة التجربة الني أعدت للاختبارات بصنف عباد الشمس فيدوك وهو هجين لإنتاج الزيت واستخدمت آلة زراعة بشفط الهواء بنيوماتيك بلانتر Pneumatic planter للزراعة على مسافات ـ سم بين الصفوف ، · r سم بين النباتات في الصف. وشقت أخاديد الرشح على مسافة . r ا سم بين كل رشاحين تم الحصاد فى اتجاه عمودي على اتجاه الزراعة. العوامل المؤثرة على أداء جهاز الدراس عند الحصاد فى الاتجاه الأمثل (D) شمال - جنوب والعكس وقد تم تحديده في تجارب سابقة كانت كالآتي:

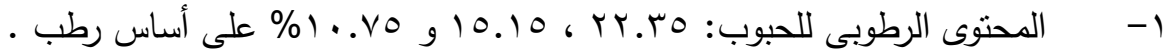

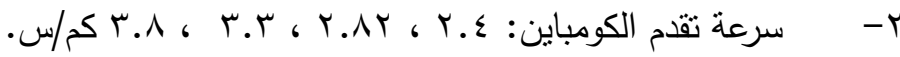

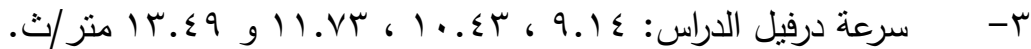

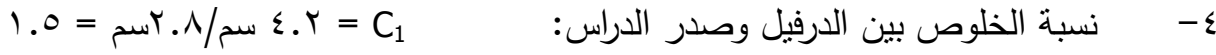

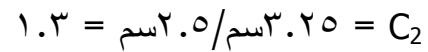

ولتحديد نأثنرات هذه العوامل تم قياس ما بلى:

1- افوافد الدراس كنسبة مئوية \%

r- بوافد الفصل كنسبة مئوية \%

r- فوافد التظظيف كنسبة مئوية \% ومن مجموع الفواقد نم حساب كفاءة نظام الحصاد \% 


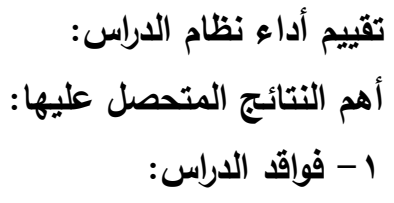

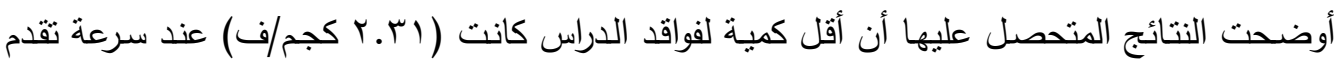

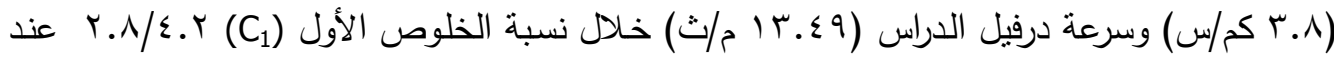

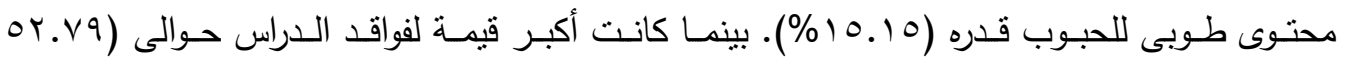
كجم/ف) وقد تحصل عليها عند سرعة تقدم (^.ب كم/س) وسرعة درفيل دراس قدرها (ع (.9 م/ث)

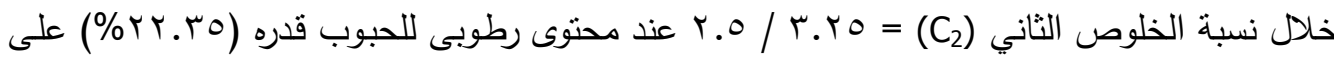

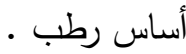

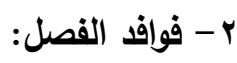
وحيث يتم الفصل خـلال شبكة صدر الدرفيل فقد أوضحت النتائج أن أقل قيمـة قواقد الفصل كانت

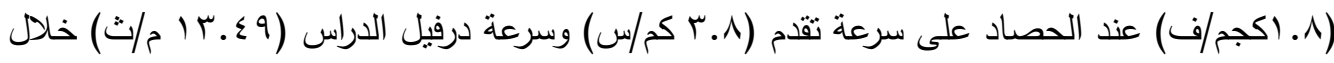
نسبة الخلوص الأول (C) تحت محتوى رطوبى للحبوب قدره (10 10 10). في حين كانت أكبر قيمة

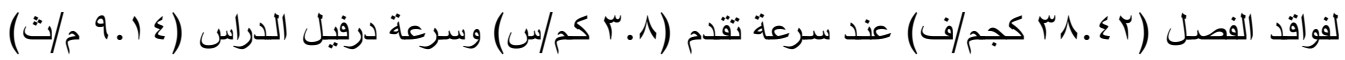

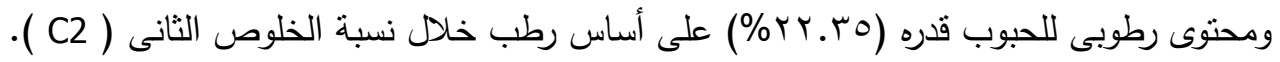
r- فاقد التنظيف:الغزابيل:

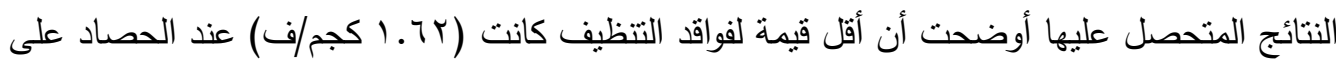

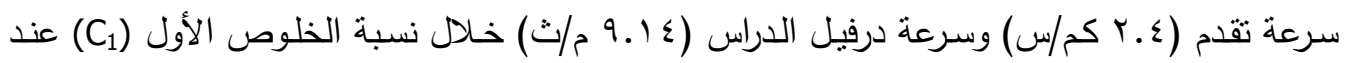

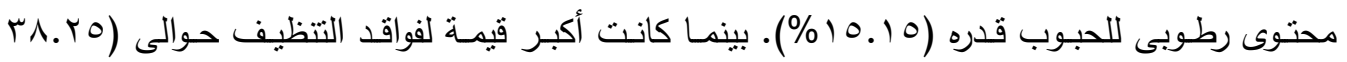

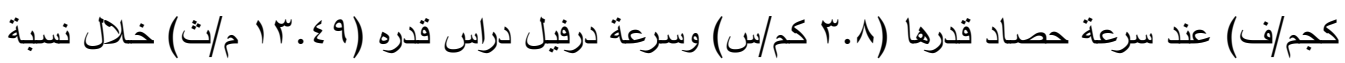

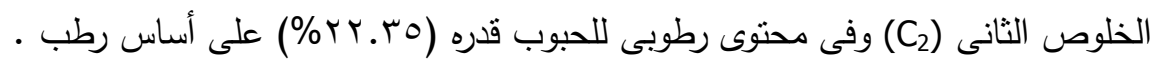
ع - الفواقد الكلية لجهاز الدراس وكفاءة الدراس: النتائج المتحصل عليها قد أثنارت إلى أقل قيمة للفواقد الكلية لجهاز الدراس كانت (T/ . • \% من الناتج

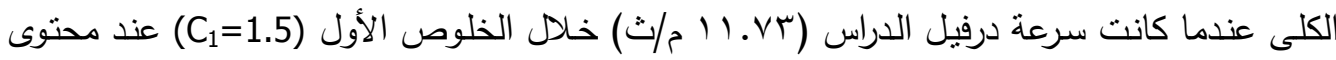

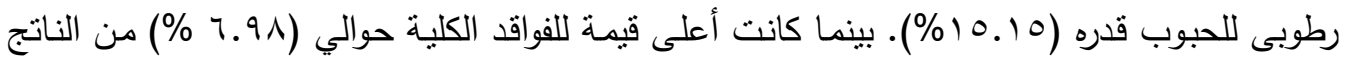

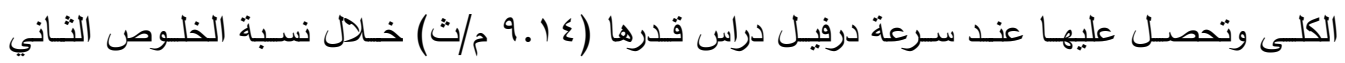

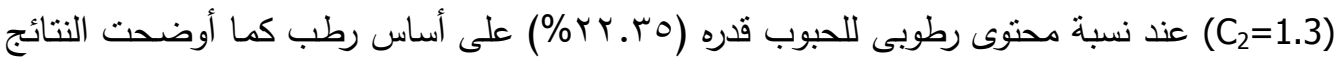

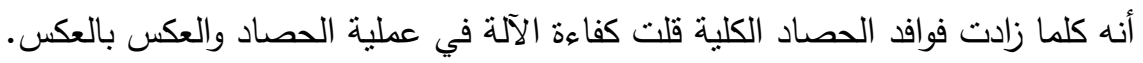

